\title{
EFFECT OF MOLE DRAINS AND COMPOST APPLICATION ON SOME SOIL PROPERTIES, WATER RELATIONS AND ITS PRODUCTIVITY AT NORTH DELTA.
}

Aiad, M.A.

Soils, Water and Environment Res. Inst., Agric. Res. Center, Egypt.

\begin{abstract}
A field experiment was conducted at Sakha Agricultural Research station, Kafr El-Sheikh Governorate, Egypt to evaluate the effect of mole drain types, mole spacing and compost application on improving some soil physio-chemical properties, some water relations and yields of wheat and sunflower. The experiments were conducted in split-split plots with four replicates.

The most important findings can be summarized as follows:

Sandy mole and narrow mole spacing effects were superior to without sandy mole and wider mole spacing on reducing soil salinity and sodicity. The reductions of salinity were $24.70,20.16$ and $10.30 \%$, respectively, after two seasons from experiment installation under mole distance of 2-m, 4-m and 6-m. While, the corresponding values of SARe were 13.41, 10.62 and $19.40 \%$, respectively. The higher reduction of soil salinity and sodcity, were noticed with increasing rates of compost in both growing seasons.

The construction of mole drain is more effective in reducing soil bulk density and increasing basic infiltration rate. The reducing soil bulk density and increasing basic infiltration rate were higher under sandy mole than mole without sand. The effect of mole spacing on reducing soil bulk density and increasing basic infiltration rate can be arranged according to the following descending order $2 \mathrm{~m}>4 \mathrm{~m}>6 \mathrm{~m}>$ compared to data obtained before treatments. The construction of mole with narrow distances between the ploughed lines seemed to be effective in increasing availability of $N, P$ and $\mathrm{K}$ especially with high rates of compost.

Sandy mole and narrow mole spacing were superior to without sandy mole and wider mole spacing on improving water application efficiency, field and crop water use efficiencies. The highest values of field and crop water use efficiencies for wheat and sunflower were achieved from the interaction between sandy mole at $6 \mathrm{~m}$ spacing combined with application of 20 ton compost fed ${ }^{-1}$.

Mole types, mole spacing and compost rates have highly significant effect on yields and yield components of wheat and sunflower. Sandy mole caused increasing of grain and straw yield of wheat than without sandy mole by 74.30 and $116.1 \%$, respectively. Also, sandy mole caused increasing of seed yield and seed oil content of sunflower than without sandy mole by $48.41 \mathrm{~kg} \mathrm{fed}^{-1}$ and $0.26 \%$, respectively. The effect of mole spacing on wheat and sunflower yields and its components can be arranged according to the following descending order $2 \mathrm{~m}>4 \mathrm{~m}>6 \mathrm{~m}$. Compost application caused high increases in wheat and sunflower yields and its components especially with the high rates. The construction of sandy moles at $2 \mathrm{~m}$ spacing combined with addition of 20 ton compost fed ${ }^{-1}$ gave the highest production of wheat grain yield( $\left.3886.7 \mathrm{~kg} \mathrm{fed}^{-1}\right)$. Keywords: mole drain, compost, soil properties, wheat, sunflower, clay soils.
\end{abstract}

\section{INTRODUCTION}

Heavy clayey salt affected soils with low permeability in the Nile Delta was not generally adapted for crop production. Therefore, an efficient 
drainage system is an important factor to improve these soils to be suitable for crop production in the short time with low cost. The major concern in these soils is to maintain of adequate water infiltration and soil aeration. A secondary drainage, such as mole drain to be an inexpensive at close spacing, intercepted by permanent laterals at wider spacing. Moling is the best suited to clay soils with a minimum clay content of about $30 \%$. Mole drain in clay soil with proper spacing can reduce waterlogging problems. Mole drain is widely used in heavy clay soils to improve the productivity (David, 2002, Moukhtar et al., 2003, and 2012 and Antar, et al., 2008 and 2012). Moling or subsoiling will enhance downward movement of irrigation water carrying off excess salts from surface layers. After wards, regular subsequent irrigations will gradually reduce the salt content in groundwater at least when close to soil surface. The percolating water will constitute a temporary front preventing the saline groundwater in subsurface soil layers from linking with the upper ones (Moukhtar et al., 2003 and 2010 and Antar, et al., 2008 and 2012). Said (2003) showed that the cumulative and basic infiltration rate of the treated soil by subsoil were markedly increased relative to the untreated one. He also pointed out that the treated soil resulted in a decrease in bulk density and penetration resistance in coincidence with an increase in total porosity and macropores relative to the untreated ones. Aiad et al., 2012 and Zamil, 2012 concluded that the ECe and ESP were decreased after mole instillation with and without sandy mole. El-Sanat (2012) revealed that the application of subsoiling at $2 \mathrm{~m}$ spacing with $110 \mathrm{~kg} \mathrm{~N}$ fed $^{-1}$ gave the highest production of wheat and crop water use efficiency.

Soil organic matter increases agricultural production by improving soil physical, chemical and biological properties. Application of organic residues could increase soil organic matter and buffer effect, improve aggregate stability and enhance water retention capacity (Spaccini et al., 2002). Compost is rich source of nutrients with high organic matter content, physical and chemical properties of soil can be improved by using compost, which may ultimately increase crop yields. Therefore, application of compost is the need of the time, physical, void ratio, water permeability and hydraulic conductivity were significantly improved when farm yard manure (10 ton ha $\left.{ }^{-1}\right)$ was applied in combination with chemical amendments, resulting in enhanced rice and wheat yields in sodic soils (Hussain et al., 2001). Other organic materials like rice straw, wheat straw and rice hulkals improved these physical properties of a saline sodic soils, which in turn significantly increased tillering, plant height, biomass and baddy yield (Hussain et al., 1998). Moreover, Gong et al. (2009), Enkeliu et al. (2010) and Yassen et al. (2010) reported that the growth and yield of wheat was improved by the use of organic fertilizer sources compared with chemical fertilizers. They added that the integrated use of organic and inorganic fertilizers get higher wheat yield.

The current study aims to evaluate the effect of mole drain types (without and with sand), mole spacing (2, 4 and $6 \mathrm{~m}$ ) and rice straw compost $\left(0,10,15\right.$ and 20 ton fed. $\left.{ }^{-1}\right)$ on improving some soil physio-chemical properties, some water relations and yields of wheat and sunflower. 


\section{MATERIALS AND METHODS}

Two field experiments were conducted at Sakha Agricultural Research Station Farm, Kafr El-Sheikh Governorate during two successive growing seasons (2010/2011 and 2011) to evaluate the effect of mole drain types, mole spacing and application rates of rice straw compost on improving some soil physio-chemical properties, some water relations and yields of wheat and sunflower. The station is situated at $31^{\circ} 05^{-} \mathrm{N}$ latitude $30^{\circ} 75^{\circ} \mathrm{E}$ longitude. It has an elevation of about 6 meters above the sea level. The soil has a clayey texture. All agricultural practices were used with the two crops as recommended in the North Delta area. The initial of some soil properties for the experimental field are presented in Table (2). The experiments were conducted in split-split plots with four replicates.

\section{The treatments were as follows:}

1- $\quad$ Main plots (mole types)

Mole without sand and mole with sand (sand-filled moles).

2- $\quad$ Sub-plots (mole spacing)

2, 4 and $6 \mathrm{~m}$ distances between the ploughed lines at $60 \mathrm{~cm}$ depth.

3- $\quad$ Sub-sub plots (compost rates of rice straw)

$0.0,10,15$ and 20 ton fed. $^{-1}$

The meterological data from Sakha Station during the two growing seasons are presented in Table (1).

In the winter season wheat (Triticum aestivum) Sakha 93 variety was planted on December 4, 2010. All plots received a total of $75 \mathrm{Kg} \mathrm{Ca}$ superphosphate/fed., during tillage operation. Nitrogen fertilizer in the form of urea was side dressed at a rate of $75 \mathrm{Kg} \mathrm{N} / \mathrm{fed}$, in two doses after 40 and 60 days from the planting. In the summer season sunflower Sakha 53 variety was sown on May, 25th and harvested on September, 15th, 2011. Phosphorus in the form of Ca-superphosphate $\left(15.5 \% \mathrm{P}_{2} \mathrm{O}_{5}\right)$ was added through preparation of the soil. Nitrogen fertilizer in the form of urea was side dressed at a rate of 45 $\mathrm{Kg} \mathrm{N} / \mathrm{fed}$ in two doses before the first and second irrigation. The different agricultural practices were performed as recommended for two crops under study. 
Table (1): Climatological data for the two growing seasons in 2010/2011

\begin{tabular}{|c|c|c|c|c|c|c|c|c|}
\hline \multirow[b]{2}{*}{ Year } & \multirow[b]{2}{*}{ Month } & \multicolumn{2}{|c|}{ Air temp. ${ }^{\circ} \mathrm{C}$} & \multirow[b]{2}{*}{ Mean } & \multirow[b]{2}{*}{$\begin{array}{c}\text { Relative } \\
\text { humidity } \\
\%\end{array}$} & \multirow{2}{*}{$\begin{array}{c}\text { Wind } \\
\text { velocity, } \\
\text { km/day } \\
\text { at } 2 \mathrm{~m} \\
\text { height }\end{array}$} & \multirow[b]{2}{*}{$\begin{array}{c}\text { Pan } \\
\text { evapo. } \\
\text { cm/day }\end{array}$} & \multirow[b]{2}{*}{$\begin{array}{c}\text { Rain, } \\
\text { mm }\end{array}$} \\
\hline & & Max. & Min. & & & & & \\
\hline \multirow{2}{*}{2010} & November & 26.8 & 11.00 & 18.90 & 68.10 & 63.00 & 0.280 & - \\
\hline & December & 22.0 & 8.30 & 15.15 & 70.10 & 58.30 & 0.181 & 20 \\
\hline \multirow{10}{*}{2011} & January & 20.3 & 5.80 & 13.05 & 69.10 & 42.50 & 0.198 & 24 \\
\hline & February & 23.4 & 7.40 & 15.40 & 70.50 & 64.00 & 0.291 & 16 \\
\hline & March & 21.8 & 6.80 & 14.30 & 67.90 & 77.40 & 0.336 & 12 \\
\hline & April & 26.5 & 10.00 & 18.25 & 66.40 & 83.40 & 0.489 & 8 \\
\hline & May & 29.0 & 13.00 & 21.00 & 57.40 & 102.50 & 0.596 & - \\
\hline & June & 32.0 & 17.20 & 24.60 & 64.50 & 113.00 & 0.722 & - \\
\hline & July & 33.0 & 19.40 & 26.20 & 64.40 & 92.00 & 0.775 & - \\
\hline & August & 32.5 & 19.20 & 25.90 & 68.00 & 84.00 & 0.683 & - \\
\hline & September & 32.2 & 17.70 & 25.00 & 68.80 & 74.00 & 0.616 & - \\
\hline & October & 28.0 & 14.00 & 21.00 & 65.00 & 78.00 & 0.451 & - \\
\hline
\end{tabular}

Table (2):The initial of some soil properties for the experimental field

\begin{tabular}{|c|c|c|c|c|c|c|c|c|}
\hline \multirow{2}{*}{$\begin{array}{c}\text { Soil } \\
\text { depth } \\
\text { (cm) }\end{array}$} & \multicolumn{3}{|c|}{$\begin{array}{l}\text { Particle size } \\
\text { distribution }\end{array}$} & \multirow{2}{*}{$\begin{array}{l}\text { Texture } \\
\text { class }\end{array}$} & \multirow[b]{2}{*}{ OM \% } & \multirow{2}{*}{$\begin{array}{c}\text { Bulk } \\
\text { density } \\
\text { g/cm }\end{array}$} & \multirow{2}{*}{$\begin{array}{c}\text { Total } \\
\text { porosity } \\
\text { E\% }\end{array}$} & \multirow{2}{*}{$\begin{array}{c}\text { Basic IR } \\
\mathrm{cm} / \mathrm{hr}\end{array}$} \\
\hline & $\begin{array}{c}\text { Sand } \\
\%\end{array}$ & $\begin{array}{c}\text { Silt } \\
\%\end{array}$ & $\underset{\%}{\text { Clay }}$ & & & & & \\
\hline $0-20$ & \multicolumn{2}{|c|}{25.8527 .34} & 46.81 & Clayey & 1.53 & .31 & 50.57 & \multirow{4}{*}{0.65} \\
\hline $20-40$ & 22.48 & 27.31 & 50.21 & Clayey & 1.45 & & & \\
\hline $40-60$ & \multicolumn{2}{|c|}{ 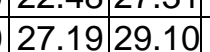 } & 43.71 & Clayey & 1.23 & 41 & 9 & \\
\hline Mean & \multicolumn{2}{|c|}{25.1727 .92} & 46.91 & Clayey & 1.40 & 1.36 & 0 & \\
\hline \multirow{2}{*}{\begin{tabular}{|c|} 
Soil \\
depth \\
(cm) \\
\end{tabular}} & \multirow{2}{*}{$\begin{array}{c}\mathrm{EC} \\
\mathrm{dS} / \mathrm{m}\end{array}$} & \multirow[b]{2}{*}{ SAR } & \multirow{2}{*}{$\begin{array}{c}\text { Field } \\
\text { capacity } \\
\%\end{array}$} & \multirow{2}{*}{\multicolumn{2}{|c|}{\begin{tabular}{c|c} 
Wilting & Available \\
point & water \\
$\%$ & $\%$ \\
\end{tabular}}} & \multicolumn{3}{|c|}{ Available nutrients, ppm } \\
\hline & & & & & & $\mathbf{N}$ & $\mathbf{P}$ & K \\
\hline $0-20$ & 6.89 & 12.96 & 42.85 & 22.76 & 20.09 & 23.80 & .51 & 31 \\
\hline $20-4$ & 7.38 & 13.42 & 40.56 & 20 & 20.26 & & 9. & \\
\hline $40-60$ & 7.87 & 13.79 & 38.25 & 20.12 & 18.13 & 19.30 & 5 & 3 \\
\hline Mean & 7.38 & 13.39 & 40.55 & 21.06 & 19.49 & 21.90 & 9.73 & 324 \\
\hline
\end{tabular}

Before planting and after harvesting both crops, soil samples $(0-20,20-$ 40 and $40-60 \mathrm{~cm}$ depth) were collected. Some physical and chemical analysis wer determined with both crops. Salinity was determined in the saturated soil paste extract according to Page (1982). Soil bulk density and total porosity of the different layers of soil profile from the applied treatments were measured before experiments and after harvesting of both seasons using the core sampling technique as described by Campbell (1994). Infiltration rate was determined using double cylinder infiltrometer as described by Garcia (1978). Wheat plant samples were taken from all treatments for determinations of 1000-kernel weight, biological, grain and straw yields as well as plant height, stem diameter, head diameter, 100-seed weight $(\mathrm{g})$ and seed yield $\left(\mathrm{kg} \mathrm{fed}^{-1}\right)$ were 
determined of sunflower. Plant samples were taken and dried at $70^{\circ} \mathrm{C}$, grounded with a mill and its available $\mathrm{N}, \mathrm{P}$ and $\mathrm{K}(\mathrm{ppm})$ content was determined. Available nitrogen was extracted using $2 \mathrm{M} \mathrm{KCl}$ and determined by the micro-kjeldahl method (Keeney and Bremner, 1966), available phosphorus was extracted using sodium bicarbonate and determined by spectronic Milton Roy by (Olsen, et al.1959) and available potassium was extracted using ammonium acetate at $\mathrm{pH} 7$ and determined by Flame photometer (Klute 1986). Sunflower seed oil was determined as described by the A.O.A.C. method (1990).

\section{Some water relations:}

Amount of irrigation water applied:

Was measured by using a set of cut-throat flumes $(30 \times 90 \mathrm{~cm})$ according to Early (1975)

\section{Determination of soil moisture percentage:}

Soil moisture content (\%) was determined by drying the soil samples at $105^{\circ} \mathrm{C}$ to constant weight and the moisture content was calculated according to Singh, (1980).

\section{Water consumptive use:}

Water consumptive use by growing plants was calculated based on soil moisture depletion (SMD) according to the following equation (Hansen et al., 1979).

$$
\mathrm{Cu}=\mathrm{SMD}=\sum_{\mathrm{i}=1}^{\mathrm{i}=4 \theta_{2}-\theta_{1}} \frac{\mathrm{Di}}{100} \times \operatorname{Dbi} \times \frac{\mathrm{i}}{100} \times 4200
$$

Where:

$\mathrm{Cu}=$ Water consumptive use $\left(\mathrm{m}^{2} / \mathrm{fed}\right.$.) in the effective root zone. $\theta_{2}=$ Gravimetric soil moisture percentage after irrigation

$\theta_{1}=$ Gravimetric soil moisture percentage before next irrigation.

Dbi=Soil bulk density $\left(\mathrm{kg} / \mathrm{m}^{3}\right)$

$\mathrm{Di}=$ Soil layer depth, $\mathrm{m}$

$i=$ Number of soil layers (1-4)

Irrigation application efficiency (Ea):

Irrigation application efficiency was calculated according to the following equation described by Downy (1970).

$\mathrm{Ea}=(\mathrm{ws} / \mathrm{wa}) \times 100$

Where:

Ws and Wa are the volumetric water stored in effective root zone and water applied, respectively.

\section{Water productivity (WP):}

Water productivity is generally defined as crop yield per cubit meter of water consumption. Water production can be also defined as crop production per unit amount of water used. Concept of water productivity in agricultural production system is focused on producing more food with the same water resources, or producing the same amount of food with less water resources. It was calculated according to Ali et al., (2007).

$$
\mathrm{WP}=\frac{\mathrm{Y}}{\mathrm{ET}}
$$




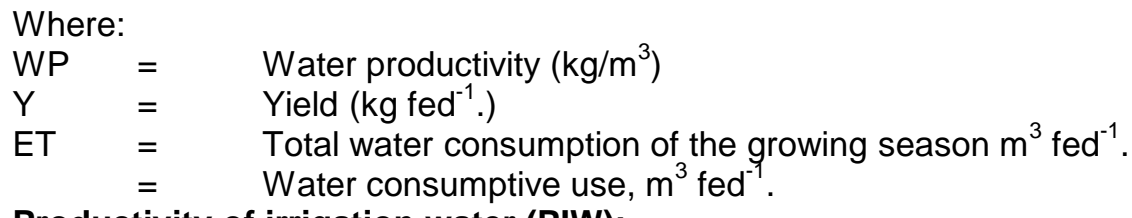

\section{Productivity of irrigation water (PIW):} et al,. (2007):

Productivity of irrigation water (PIW) was calculated according to Ali

$$
\mathrm{PIW}=\frac{\mathrm{Y}}{\mathrm{IW}}
$$

Where:

$\begin{array}{lll}\text { PIW } & = & \text { Productivity of irrigation water }\left(\mathrm{kg} / \mathrm{m}^{3}\right) \\ \mathrm{Y} & = & \text { Yield }\left(\mathrm{kg} \mathrm{fed}^{-1}\right) \\ \mathrm{IW} & = & \text { Irrigation water applied, } \mathrm{m}^{3} \mathrm{fed}^{-1} .\end{array}$

Statistical analysis: Data obtained are subjected to statistical analysis according to Snedecor and Cochran (1980).

\section{RESULTS AND DISCUSSIONS}

\section{Soil salinity (ECe) and sodicity (SARe):}

Salinity and sodicity of the soil as affected by different mole types, mole spacing and compost rates under wheat and sunflower cultivation are shown in Table (3). Data clearly showed that the construction of mole drain is more effective in decreasing of soil salinity and sodicity than before experiment instillation in the topsoil up to $60 \mathrm{~cm}$ depth. The mean values of ECe and SARe before experiment were $7.38 \mathrm{dS} / \mathrm{m}$ and 13.39, respectively. While, after treatments installation values of $\mathrm{EC}_{\mathrm{e}}$ varied from 5.11 to $6.95 \mathrm{dS} / \mathrm{m}$ and SARe from 10.92 to 13.02 under all treatments for both seasons. Data also, showed that sandy mole effects were superior to without sandy mole on reducing soil salinity and sodicity. The reduction in soil salinity were higher under mole without sandy and mole with sand, respectively about 14.89 and $18.08 \%$ in first season, 19.31 and $22.23 \%$ in the second season than before experiment. The corresponding values of SARe were 7.50 and $9.48 \%, 10.13$ and $11.94 \%$, respectively.

Concerning mole drain spacing, results in Table (3) showed that, ECe and SARe of soil are decreased with decreasing mole drain spacing in both growing seasons. The reductions of salinity were 24.7, 20.16 and $10.3 \%$, respectively under mole distance of 2,4 and $6-\mathrm{m}$ after harvesting of both crops. The corresponding values of SARe were 13.41, 10.62 and $19.40 \%$, respectively. Results could be attributed mainly to that mole forms many lines with big crack extent from soil surface to mole depth $(50-60 \mathrm{~cm}$ deep) and also numerous effective capillary cracks is formed. All these cracks together break the soil matrix and encourage downward of water as well as solute movement. The soil cracks life may be several months or years (Moukhtar et al, 2002a and Antar et al., 2012). Moukhtar et al, (2003b) reported that, moling or subsoiling enhance downward movement of irrigation 
water carrying off excess salts from surface layers. After wards, regular subsequent irrigations will gradually reduce the salt content in groundwater at least when it is close to soil surface. The percolating water will constitute a temporary front preventing the saline groundwater in subsurface soil layers from linking with the upper ones. These results are in agreement with those obtained by El-Sanat (2012) and Zamil (2012).

Table (3):ECe and SARe of soil (0-60 cm depth) before experiments and after harvesting wheat and sunflower.

\begin{tabular}{|c|c|c|c|c|c|c|c|c|c|c|}
\hline \multirow{2}{*}{\multicolumn{3}{|c|}{ Treatments }} & \multirow{2}{*}{$\begin{array}{l}\mathrm{ECe} \\
\mathrm{dS} / \mathrm{m}\end{array}$} & \multirow{2}{*}{ SARe } & \multicolumn{2}{|c|}{$\begin{array}{l}\text { Rate of } \\
\text { change }\end{array}$} & \multirow{2}{*}{$\begin{array}{l}\mathrm{ECe} \\
\mathrm{dS} / \mathrm{m}\end{array}$} & \multirow{2}{*}{ SARe } & \multicolumn{2}{|c|}{ Rate of change } \\
\hline & & & & & $\mathrm{ECe}$ & SARe & & & $\mathrm{ECe}$ & SARe \\
\hline \multirow[b]{3}{*}{$\begin{array}{l}\text { Mole } \\
\text { type }\end{array}$} & & & \multicolumn{8}{|c|}{ Before experiments } \\
\hline & & & 7.38 & 13.39 & - & - & 7.38 & 13.39 & - & - \\
\hline & \multirow[t]{2}{*}{$\begin{array}{c}\text { Mole } \\
\text { spacing } \\
\mathrm{m}\end{array}$} & \multirow{2}{*}{$\begin{array}{c}\text { Compost } \\
\text { rates } \\
\text { ton fed }^{-1} \\
0\end{array}$} & \multicolumn{4}{|c|}{$\begin{array}{c}\text { After one season (wheat } \\
\text { crop) }\end{array}$} & \multicolumn{4}{|c|}{$\begin{array}{c}\text { After two seasons (sunflower } \\
\text { crop) }\end{array}$} \\
\hline \multirow{15}{*}{ Mole } & & & 6.29 & 12.38 & 14.77 & 7.54 & 6.11 & 12.18 & 17.21 & 9.04 \\
\hline & \multirow{3}{*}{$2-m$} & 10 & 6.05 & 12.12 & 18.02 & 9.48 & 5.76 & 11.85 & 21.95 & 11.5 \\
\hline & & 15 & 5.89 & 11.98 & 20.19 & 10.53 & 5.53 & 11.6 & 25.08 & 13.37 \\
\hline & & 20 & 5.65 & 11.74 & 23.44 & 12.32 & 5.37 & 11.43 & 27.24 & 14.64 \\
\hline & \multicolumn{2}{|c|}{ Mean } & 5.97 & 12.06 & 19.11 & 9.67 & 5.69 & 11.77 & 22.87 & 12.14 \\
\hline & \multirow{4}{*}{ 4-m } & 0 & 6.63 & 12.71 & 10.16 & 5.08 & 6.39 & 12.48 & 13.41 & 6.79 \\
\hline & & 10 & 6.49 & 12.69 & 12.06 & 5.23 & 6.18 & 12.25 & 16.26 & 8.51 \\
\hline & & 15 & 6.15 & 12.25 & 16.67 & 8.51 & 5.91 & 11.99 & 19.92 & 10.46 \\
\hline & & 20 & 6.02 & 12.11 & 18.43 & 9.56 & 5.63 & 11.7 & 23.71 & 12.62 \\
\hline & \multicolumn{2}{|c|}{ Mean } & 6.32 & 12.44 & 14.33 & 7.1 & 6.03 & 12.11 & 18.33 & 9.59 \\
\hline & \multirow{4}{*}{ 6-m } & 0 & 6.95 & 13.02 & 5.83 & 2.76 & 6.53 & 12.6 & 11.52 & 5.89 \\
\hline & & 10 & 6.75 & 12.8 & 8.54 & 4.41 & 6.24 & 12.32 & 15.45 & 7.99 \\
\hline & & 15 & 6.35 & 12.42 & 13.96 & 7.24 & 6.03 & 12.12 & 18.29 & 9.48 \\
\hline & & 20 & 6.15 & 12.25 & 16.67 & 8.51 & 5.78 & 11.88 & 21.68 & 11.28 \\
\hline & \multicolumn{2}{|c|}{ Mean } & 6.55 & 12.62 & 11.25 & 5.73 & 6.15 & 12.23 & 16.74 & 8.66 \\
\hline \multicolumn{3}{|c|}{ Mean } & 6.28 & 12.37 & 14.89 & 7.5 & 5.96 & 12.04 & 19.31 & 10.13 \\
\hline \multirow{15}{*}{$\begin{array}{l}\text { Sandy } \\
\text { mole }\end{array}$} & \multirow{4}{*}{$2-m$} & 0 & 6.05 & 12.12 & 18.02 & 9.48 & 5.75 & 11.82 & 22.09 & 11.77 \\
\hline & & 10 & 5.95 & 12.05 & 19.38 & 10 & 5.54 & 11.6 & 24.93 & 13.37 \\
\hline & & 15 & 5.75 & 11.82 & 22.09 & 11.73 & 5.29 & 11.36 & 28.32 & 15.16 \\
\hline & & 20 & 5.31 & 11.36 & 28.05 & 15.16 & 5.11 & 10.92 & 30.76 & 18.45 \\
\hline & \multicolumn{2}{|c|}{ Mean } & 5.77 & 11.84 & 21.89 & 11.59 & 5.42 & 11.43 & 26.53 & 14.68 \\
\hline & \multirow{4}{*}{ 4-m } & 0 & 6.43 & 12.51 & 12.87 & 6.57 & 6.05 & 12.12 & 18.02 & 9.48 \\
\hline & & 10 & 6.09 & 12.18 & 17.48 & 9.04 & 5.85 & 11.92 & 20.73 & 10.98 \\
\hline & & 15 & 5.91 & 11.98 & 19.92 & 10.53 & 5.65 & 11.74 & 23.44 & 12.32 \\
\hline & & 20 & 5.85 & 11.92 & 20.73 & 10.98 & 5.48 & 11.54 & 25.75 & 13.82 \\
\hline & $\mathrm{Me}$ & an & 6.07 & 12.15 & 17.75 & 9.28 & 5.76 & 11.83 & 21.99 & 11.65 \\
\hline & & 0 & 6.74 & 12.8 & 8.67 & 4.41 & 6.45 & 12.54 & 12.6 & 6.35 \\
\hline & $m$ & 10 & 6.38 & 12.48 & 13.55 & 6.79 & 6.11 & 12.18 & 17.21 & 9.04 \\
\hline & $b-m$ & 15 & 6.11 & 12.18 & 17.21 & 9.04 & 5.91 & 11.98 & 19.92 & 10.53 \\
\hline & & 20 & 5.98 & 12.05 & 18.97 & 10.01 & 5.69 & 11.78 & 22.89 & 12.02 \\
\hline & & & 6.3 & 12.38 & 14.6 & 7.56 & 6.04 & 12.12 & 18.16 & 9.49 \\
\hline Mean & & & 6.05 & 12.12 & 18.08 & 8.48 & 5.74 & 11.79 & 22.23 & 11.94 \\
\hline
\end{tabular}

Application of rice straw compost reduced soil salinity and sodcity. The higher reduction of soil salinity and sodcity, were noticed with increasing rates of compost. The decreases of soil salinity and sodicity with application compost harvesting of are more pronounced after harvesting the second 
season compared to after harvesting of the first season (Table, 3). This may be due to the improved soil physical properties such as bulk density, porosity, aggregates stability and infiltration rate that affect water-air relationships in the root zone (Doran and Parking, 1994).

\section{Soil bulk density and total porosity:}

Soil bulk density is considered as one of the most important parameters which indicate the status of soil structure and consequently, soil water, air and heat regime (Richards, 1954). Results in Table (4) show that, soil bulk density was reduced after harvesting of first and second seasons. The average value of soil bulk density was $1.36 \mathrm{Mgm}^{3}$ before installation of the treatments and, its values were 1.25 and $1.21 \mathrm{Mgm}^{3}$ after harvesting of the first and second seasons, respectively. Data also showed that soil bulk density after the second season was somewhat reduce under mole filled with sand $\left(1.24 \mathrm{Mgm}^{3}\right)$ compared to mole without sand $\left(1.26 \mathrm{Mgm}^{3}\right)$. The narrow distances between the ploughed lines seemed to be effective in lowering soil bulk density than wider mole spacing. The lowest values are achieved with 2 $\mathrm{m}$ spacing while the highest values were obtained with $6 \mathrm{~m}$ mole spacing (Table 4). This means that mole effects were superior to those obtained before application the treatments on reducing soil bulk density. It could be attributed to the effects of mole types or distances on breaking soil clods and bigger granular into smaller crumbs as well as breaking and cracking the compacted layers (Amer, 1999, Abdel-Mawgoud et al., 2006 and Antar et al., 2008). Results show also that, applied of rice straw compost led to reduce soil bulk density especially with the high rates and after harvesting of the second season. The beneficial effect of compost in improving the bulk density is due to the increase of soil organic matter content which consequently encourages soil aggregates.

Soil porosity values (Table, 4) had taken almost the opposite trend to that encountered with bulk density. The results indicate that the values of bulk density were increased and values of total porosity were decreased for all treatments (Table, 4).

Infiltration rate:

The basic infiltration rate (BIR) as affected by different mole types, mole spacing and compost rates under wheat and sunflower cultivation are shown in Table (4). Data showed that the construction of mole drain is more effective in increasing BIR compared to data obtained before experiment instillation. The mean value of BIR before experiment was $0.65 \mathrm{cmhr}^{-1}$ while, after treatments installation values of BIR varied from 0.95 to $1.45 \mathrm{cmhr}^{-1}$ under all treatments for both seasons. Data also, showed that sandy mole effects were superior to without sandy mole on increasing BIR. The increasing in BIR were higher under mole filled with sand than without sandy mole about $0.2 \mathrm{cmhr}^{-1}$ in first season and $0.1 \mathrm{cmhr}^{-1}$ in the second season. 
Table (4): Soil bulk density, total porosity (0-60 $\mathrm{cm}$ depth) and basic infiltration rate (IR) before experiments and after harvesting of wheat and sunflower for all treatments.

\begin{tabular}{|c|c|c|c|c|c|c|c|c|}
\hline \multicolumn{3}{|c|}{ Treatments } & $\begin{array}{c}\text { Soil bulk } \\
\text { density } \\
\left(\mathrm{Mg} / \mathrm{m}^{3}\right)\end{array}$ & $\begin{array}{c}\text { Soil } \\
\text { porosity } \\
(\%)\end{array}$ & $\begin{array}{c}\text { IR } \\
\left(\mathrm{cmhr}^{-1}\right)\end{array}$ & $\begin{array}{c}\text { Soil bulk } \\
\text { density } \\
\left(\mathrm{Ma} / \mathrm{m}^{3}\right)\end{array}$ & $\begin{array}{c}\text { Soil } \\
\text { porosity } \\
(\%)\end{array}$ & $\begin{array}{c}\text { IR } \\
\left(\mathrm{cmhr}^{-1}\right)\end{array}$ \\
\hline \multirow{3}{*}{$\begin{array}{l}\text { Mole } \\
\text { type }\end{array}$} & \multirow{3}{*}{$\begin{array}{c}\text { Mole } \\
\text { spacing } \\
\text { m }\end{array}$} & \multirow{3}{*}{$\begin{array}{c}\text { Compost } \\
\text { rates } \\
\text { ton fed }\end{array}$} & \multicolumn{6}{|c|}{ Before experiments } \\
\hline & & & 1.36 & 48.80 & 0.65 & 1.36 & 48.80 & 0.65 \\
\hline & & & \multicolumn{3}{|c|}{ After one season (wheat crop) } & \multicolumn{3}{|c|}{$\begin{array}{c}\text { After two seasons (sunflower } \\
\text { crop) }\end{array}$} \\
\hline \multirow{6}{*}{ Mole } & $2-m$ & $\begin{array}{c}0 \\
10 \\
15 \\
20 \\
\end{array}$ & $\begin{array}{l}1.31 \\
1.29 \\
1.26 \\
1.24 \\
\end{array}$ & $\begin{array}{l}50.57 \\
51.32 \\
52.45 \\
53.20 \\
\end{array}$ & 1.15 & $\begin{array}{l}1.28 \\
1.26 \\
1.23 \\
1.22 \\
\end{array}$ & $\begin{array}{l}51.69 \\
52.45 \\
53.58 \\
53.96 \\
\end{array}$ & 1.36 \\
\hline & \multicolumn{2}{|c|}{ Mean } & 1.28 & 51.89 & & 1.25 & 52.92 & \\
\hline & $4-m$ & $\begin{array}{c}0 \\
10 \\
15 \\
20\end{array}$ & $\begin{array}{l}1.32 \\
1.31 \\
1.29 \\
1.27\end{array}$ & $\begin{array}{l}50.19 \\
50.67 \\
51.32 \\
52.08\end{array}$ & 1.05 & $\begin{array}{l}1.29 \\
1.28 \\
1.25 \\
1.23\end{array}$ & $\begin{array}{l}51.32 \\
51.69 \\
52.83 \\
53.58\end{array}$ & 1.25 \\
\hline & \multicolumn{2}{|c|}{ Mean } & 1.30 & 51.07 & & 1.26 & 52.36 & \\
\hline & $6-\mathrm{m}$ & $\begin{array}{c}0 \\
10 \\
15 \\
20\end{array}$ & $\begin{array}{l}1.34 \\
1.32 \\
1.30 \\
1.28\end{array}$ & $\begin{array}{l}49.43 \\
50.19 \\
50.94 \\
51.69\end{array}$ & 0.95 & $\begin{array}{l}1.30 \\
1.28 \\
1.26 \\
1.24\end{array}$ & $\begin{array}{l}50.94 \\
51.69 \\
52.45 \\
53.20\end{array}$ & 1.11 \\
\hline & \multicolumn{2}{|c|}{ Mean } & 1.31 & 50.56 & & 1.27 & 52.07 & \\
\hline \multicolumn{3}{|c|}{ Mean } & 1.30 & 51.17 & 1.05 & 1.26 & 52.45 & 1.24 \\
\hline \multirow{6}{*}{$\begin{array}{l}\text { Sand } \\
\text { mole }\end{array}$} & $2-m$ & $\begin{array}{c}0 \\
10 \\
15 \\
20\end{array}$ & $\begin{array}{l}1.27 \\
1.25 \\
1.21 \\
1.18\end{array}$ & $\begin{array}{l}52.08 \\
52.83 \\
54.34 \\
55.47\end{array}$ & 1.35 & $\begin{array}{l}1.22 \\
1.20 \\
1.17 \\
1.12\end{array}$ & $\begin{array}{l}53.96 \\
54.72 \\
55.85 \\
57.74\end{array}$ & 1.45 \\
\hline & \multicolumn{2}{|c|}{ Mean } & 1.23 & 53.68 & & 1.18 & 55.57 & \\
\hline & $4-m$ & $\begin{array}{c}0 \\
10 \\
15 \\
20\end{array}$ & $\begin{array}{l}1.28 \\
1.26 \\
1.24 \\
1.21\end{array}$ & $\begin{array}{l}51.69 \\
52.45 \\
53.20 \\
54.34\end{array}$ & 1.23 & $\begin{array}{l}1.25 \\
1.23 \\
1.22 \\
1.15\end{array}$ & $\begin{array}{l}52.83 \\
53.58 \\
53.96 \\
56.60\end{array}$ & 1.32 \\
\hline & \multicolumn{2}{|c|}{$\frac{1}{\text { Mean }}$} & 1.25 & 52.92 & & 1.21 & 54.24 & \\
\hline & $6-\mathrm{m}$ & $\begin{array}{c}0 \\
10 \\
15 \\
20\end{array}$ & $\begin{array}{l}1.29 \\
1.28 \\
1.26 \\
1.24\end{array}$ & $\begin{array}{l}51.32 \\
51.69 \\
52.45 \\
53.20\end{array}$ & 1.21 & $\begin{array}{l}1.27 \\
1.25 \\
1.24 \\
1.18\end{array}$ & $\begin{array}{l}52.08 \\
52.83 \\
53.20 \\
55.47\end{array}$ & 1.26 \\
\hline & \multirow{2}{*}{\multicolumn{2}{|c|}{ Mean }} & 1.27 & 52.17 & & 1.24 & 53.39 & \\
\hline Mean & & & 1.25 & 52.92 & 1.26 & 1.21 & 54.40 & 1.34 \\
\hline
\end{tabular}

Concerning the effect of drain spacing on the basic infiltration rate, data show that, $2 \mathrm{~m}$ spacing increased the basic infiltration rate more than the other drain spacing. The effect of mole spacing on the basic infiltration rate can be arranged according to the following descending order $2 \mathrm{~m}>4 \mathrm{~m}>6 \mathrm{~m}$ $>$ compared to data obtained before planting treatments. This may be due to the subsurface tillage such as mole drain gave the top soil layer a chance to dry and permitted for shrinkage and formation of water passage ways which allowed a rather easier movement of water into mole or subsoil line. Similar results were obtained by Abdel-Mawgoud et al., (2006) and Antar et al. (2012). 


\section{Available nutrients:}

Results in Table (5) show that, availability of N, P and $\mathrm{K}$ were increased after harvesting of both crops as a result of applied treatments (mole types and spacings as well as compost rates). The average values of $\mathrm{N}, \mathrm{P}$ and $\mathrm{K}$ were $21.90,9.73$ and $324.0 \mathrm{ppm}$, respectively before conducting the treatments. While, after treatments installation values of $\mathrm{N}, \mathrm{P}$ and $\mathrm{K}$ were varied from 24.79 to $88.60 \mathrm{ppm}, 9.45$ to $18.10 \mathrm{ppm}$ and 315.60 to 485.00 ppm, respectively under all treatments for both seasons.

Table (5): Available of $\mathrm{N}, \mathrm{P}$ and $\mathrm{K}$ (ppm) in soil before and after harvesting of wheat and sunflower under all treatments.

\begin{tabular}{|c|c|c|c|c|c|c|c|c|}
\hline \multicolumn{3}{|c|}{ Treatments } & $\mathbf{N}$ & $\mathbf{P}$ & $\mathbf{K}$ & $\mathbf{N}$ & $\mathbf{P}$ & $\mathrm{K}$ \\
\hline \multirow{3}{*}{$\begin{array}{l}\text { Mole } \\
\text { type }\end{array}$} & \multirow{3}{*}{$\begin{array}{c}\text { Mole } \\
\text { spacing } \\
\text { m }\end{array}$} & \multirow{3}{*}{$\begin{array}{c}\text { Compost } \\
\text { rates } \\
\text { ton fed }^{-1}\end{array}$} & \multicolumn{6}{|c|}{ Before experiments } \\
\hline & & & 21.90 & 9.73 & 324.0 & 21.90 & 9.73 & 324.00 \\
\hline & & & \multicolumn{3}{|c|}{$\begin{array}{c}\text { After one season } \\
\text { (wheat crop) }\end{array}$} & \multicolumn{3}{|c|}{$\begin{array}{l}\text { After two seasons } \\
\text { (sunflower crop) }\end{array}$} \\
\hline \multirow{12}{*}{ Mole } & \multirow{4}{*}{$2-m$} & 0 & 46.50 & 12.35 & 375.0 & 33.53 & 10.41 & 341.51 \\
\hline & & 10 & 65.10 & 13.65 & 408.0 & 59.92 & 11.82 & 382.6 \\
\hline & & 15 & 70.20 & 15.71 & 423.0 & 66.32 & 13.15 & 413.7 \\
\hline & & 20 & 82.70 & 17.20 & 445.0 & 76.80 & 15.75 & 426.5 \\
\hline & \multirow{4}{*}{ 4-m } & 0 & 37.30 & 11.78 & 355.8 & 26.57 & 9.65 & 326.98 \\
\hline & & 10 & 46.40 & 12.83 & 369.7 & 42.62 & 10.33 & 361.56 \\
\hline & & 15 & 53.40 & 14.31 & 390.5 & 46.68 & 12.38 & 355.70 \\
\hline & & 20 & 72.80 & 15.80 & 410.9 & 78.51 & 14.19 & 395.80 \\
\hline & \multirow{4}{*}{$6-m$} & 0 & 33.60 & 11.63 & 335.8 & 24.79 & 9.45 & 319.50 \\
\hline & & 10 & 39.50 & 12.91 & 346.5 & 38.50 & 10.11 & 328.43 \\
\hline & & 15 & 48.30 & 13.39 & 356.8 & 41.85 & 11.75 & 337.80 \\
\hline & & 20 & 65.40 & 14.11 & 385.5 & 56.37 & 13.89 & 368.90 \\
\hline \multirow{12}{*}{$\begin{array}{l}\text { Sand } \\
\text { mole }\end{array}$} & \multirow{4}{*}{$2-m$} & 0 & 49.2 & 12.90 & 391.0 & 41.82 & 11.38 & 365.2 \\
\hline & & 10 & 71.8 & 14.20 & 435.0 & 66.30 & 12.67 & 315.6 \\
\hline & & 15 & 78.4 & 16.30 & 462.0 & 71.20 & 14.12 & 436.5 \\
\hline & & 20 & 88.6 & 18.10 & 485.0 & 82.70 & 16.91 & 445.1 \\
\hline & \multirow{4}{*}{ 4-m } & 0 & 42.9 & 12.30 & 375.0 & 37.60 & 10.40 & 359.10 \\
\hline & & 10 & 56.9 & 13.15 & 385.0 & 51.80 & 11.30 & 376.50 \\
\hline & & 15 & 69.4 & 14.60 & 415.0 & 63.50 & 13.20 & 392.00 \\
\hline & & 20 & 83.2 & 16.50 & 448.0 & 79.50 & 15.60 & 416.00 \\
\hline & \multirow{4}{*}{ 6-m } & 0 & 36.5 & 11.92 & 363.0 & 32.90 & 9.75 & 351.50 \\
\hline & & 10 & 47.7 & 13.12 & 370.0 & 43.80 & 11.50 & 346.50 \\
\hline & & 15 & 61.3 & 13.60 & 380.0 & 53.70 & 12.70 & 365.50 \\
\hline & & 20 & 76.5 & 14.10 & 425.0 & 69.40 & 13.20 & 390.50 \\
\hline
\end{tabular}

The narrow distances between the ploughed lines and sandy mole seemed to be effective in increasing availability of $\mathrm{N}, \mathrm{P}$ and $\mathrm{K}$ compared to wider mole spacing and mole without sand. This is due to improved drainage conditions near the drain line which caused water-air balance in the root zone, and increasing the amount of available nutrients for the plant. Similar results were obtained by Moustafa et al. (1987), Sharma and Komal (1998) and Ibrahim et al. (1999). Also, compost application led to high increases in availability of $\mathrm{N}, \mathrm{P}$ and $\mathrm{K}$ especially with the high rates. The beneficial effect of compost in improving the availability of $\mathrm{N}, \mathrm{P}$ and $\mathrm{K}$ are due to the increase 
of soil organic matter content which consequently encourages soil aggregate, which caused water-air balance in the root zone, and consequently increasing the amount of available nutrients. The same results were obtained by Shams El-Din (2001).

Some water relations:

\section{Amount of irrigation water applied:}

The average amount of irrigation water included the rainfall delivered to each treatment is presented in Table (6). The mole drain spacing at $6 \mathrm{~m}$ received the lowest amount of irrigation water as compared to $2 \mathrm{~m}$ and $4 \mathrm{~m}$ spacing. Also, mole without sand received the lowest amount of water applied, compared to sandy mole. It is obvious from the obtained data that the highest values of water applied to wheat are obtained with sandy mole at $2 \mathrm{~m}$ spacing $\left(2517.53 \mathrm{~m}^{3} \mathrm{fed}^{-1}\right.$.), while the lowest value was recorded with 6 $\mathrm{m}$ spacing under mole without sand treatment $\left(1947.81 \mathrm{~m}^{3} \mathrm{fed}^{-1}\right.$.). Also, the highest value of water applied to sunflower was recorded with sandy mole at $2 \mathrm{~m}$ spacing $\left(2736.9 \mathrm{~m}^{3} \mathrm{fed}^{-1}\right.$.), while the lowest value is obtained under mole without sand at $6 \mathrm{~m}$ spacing $\left(2224.83 \mathrm{~m}^{3} \mathrm{fed}^{-1}\right.$.). These results are in agreement with those obtained by Zamil (2012) and El-Sanat (2012).

Water consumptive use:

Results in Table (6) showed that, there were no obvious differences between water consumptive use values under mole types and mole spacing treatments for either wheat and sunflower crops. The mean values of water consumptive use were 1248.07 and $1251.73 \mathrm{~m}^{3}$ fed $^{-1}$, for without sandy mole and sandy mole, respectively under wheat and it were 1372.91 and 1390.02 $\mathrm{m}^{3} \mathrm{fed}^{-1}$ under sunflower. Water consumptive use for both wheat and sunflower were decreased with the increasing mole spacing (from 2 to $6 \mathrm{~m}$ ). Water consumptive use mean values were 1268.6, 1262.6 and 1218.6 with wheat and 1464.2, 1274.9 and 1305.3 with sunflower for 2-m, 4-m and 6-m mole spacing, respectively. This finding is supported by Zamil (2012) and El-Sanat (2012).

Water application efficiency:

Data in Table (6) show that, water application efficiency mean values were 59.09 and $62.63 \%$ for sandy mole and mole without sand, respectively under wheat crop. The corresponding values were 71.39 and $69.68 \%$, respectively under sunflower. Results in Table (6) show that, the narrow mole spacing was superior to wider mole spacing on improving water application efficiency. The mean values of water application efficiency were $56.18,60.12$ and $66.29 \%$ under wheat and its values were $69.20,70.59$ and 71.83 for 2-m, 4$\mathrm{m}$ and 6-m mole spacing, respectively under sunflower. These results are in agreement with those of Zamil (2012) and El-Sanat (2012).

Field and crop water use efficiencies (productivity of irrigation water):

Data in Table (7) show that, the establishment of more grain types and its seemed to be effective in producing relatively high values of field and crop water use efficiency for both crops. Mole types resulted in somewhat different for field and crop water use efficiency. Field water use efficiency mean values of wheat for sandy mole and mole without sand were 1.39 and 1.34, for grain and 1.71 and $1.63 \mathrm{~kg} / \mathrm{m}^{3}$, respectively for straw. The corresponding values of crop water use efficiency were 2.40 and $2.57 \mathrm{~kg} / \mathrm{m}^{3}$, for grain and 2.93 and 3.02 
$\mathrm{kg} / \mathrm{m}^{3}$ for straw, respectively. The mean values of field and crop water use efficiency with sunflower were 0.41 and $0.71 \mathrm{~kg}$ seed $/ \mathrm{m}^{3}$, respectively for sandy mole and 0.41 and $0.73 \mathrm{~kg} \mathrm{seed} / \mathrm{m}^{3}$, respectively for mole without sand.

The narrow mole spacing were superior to wider mole spacing on reducing field water use efficiency and increasing crop water use efficiency. Field water use efficiency mean values of wheat for 2-m, 4-m and 6-m mole spacing were $1.31,1.36$ and $1.44 \mathrm{~kg} / \mathrm{m}^{3}$ with grain and $1.61,1.66$ and $1.75 \mathrm{~kg} / \mathrm{m}^{3}$, respectively with straw. On the other hand, crop water use efficiency mean values for 2-m, 4$\mathrm{m}$ and $6-\mathrm{m}$ mole spacing were $2.53,2.52$ and $2.41 \mathrm{~kg} / \mathrm{m}^{3}$ with grain and 3.08 , 2.93 and $2.91 \mathrm{~kg} / \mathrm{m}^{3}$, respectively with straw. The mean values of field \&crop water use efficiency of sunflower were $0.39,0.41$ and $0.42 \mathrm{~kg} / \mathrm{m}^{3} \& 0.71,0.72$ and $0.74 \mathrm{~kg} \mathrm{seed} / \mathrm{m}^{3}$ for 2-m, 4-m and 6-m mole spacing, respectively.

Table (6): Water applied, water consumptive use and water application efficiency as affected by different treatments under cultivation of wheat and sunflower crops.

\begin{tabular}{|c|c|c|c|c|c|c|c|c|}
\hline \multirow[b]{2}{*}{$\begin{array}{l}\text { Mole } \\
\text { type }\end{array}$} & \multirow[b]{2}{*}{$\begin{array}{c}\text { Mole } \\
\text { spacing } \\
\text { (m) }\end{array}$} & \multirow[b]{2}{*}{$\begin{array}{l}\text { Compost } \\
\text { rates } \\
\text { ton } \text { fed }^{-1}\end{array}$} & \multicolumn{3}{|c|}{ Wheat crop } & \multicolumn{3}{|c|}{ Sunflower crop } \\
\hline & & & $\begin{array}{c}\text { Water } \\
\text { applied } \\
\left(\mathrm{m}^{3} \mathrm{fed}^{-1}\right)\end{array}$ & $\begin{array}{c}\text { Water } \\
\text { consumptive } \\
\text { use } \\
\left(\mathrm{m}^{3} \mathrm{fed}^{-1}\right)\end{array}$ & $\begin{array}{c}\text { Water } \\
\text { application } \\
\text { efficiency } \\
(\%)\end{array}$ & $\begin{array}{l}\text { Water } \\
\text { applied } \\
\left(\mathrm{m}^{3} \mathrm{fed}^{-1}\right)\end{array}$ & $\begin{array}{c}\text { Water } \\
\text { consumptive } \\
\text { use } \\
\left(\mathrm{m}^{3} \mathrm{fed}^{-1}\right)\end{array}$ & $\begin{array}{c}\text { Water } \\
\text { application } \\
\text { efficiency } \\
(\%)\end{array}$ \\
\hline \multirow{12}{*}{ Mole } & \multirow{4}{*}{$2-m$} & 0 & \multirow{4}{*}{2349.30} & \multirow{4}{*}{1271.50} & \multirow{4}{*}{57.37} & \multirow{4}{*}{2526.70} & \multirow{4}{*}{1438.87} & \multirow{4}{*}{69.35} \\
\hline & & 10 & & & & & & \\
\hline & & 15 & & & & & & \\
\hline & & 20 & & & & & & \\
\hline & \multirow{4}{*}{$4-m$} & 0 & \multirow{4}{*}{2145.92} & \multirow{4}{*}{1260.80} & \multirow{4}{*}{62.19} & \multirow{4}{*}{2365.80} & \multirow{4}{*}{1367.95} & \multirow{4}{*}{68.26} \\
\hline & & 10 & & & & & & \\
\hline & & 15 & & & & & & \\
\hline & & 20 & & & & & & \\
\hline & \multirow{4}{*}{$6-m$} & 0 & \multirow{4}{*}{1947.81} & \multirow{4}{*}{1211.90} & \multirow{4}{*}{68.33} & \multirow{4}{*}{2224.83} & \multirow{4}{*}{1311.90} & \multirow{4}{*}{71.44} \\
\hline & & 10 & & & & & & \\
\hline & & 15 & & & & & & \\
\hline & & 20 & & & & & & \\
\hline \multicolumn{3}{|c|}{ Mean } & 2147.68 & 1248.07 & 62.63 & 2372.44 & 1372.91 & 69.68 \\
\hline \multirow{12}{*}{$\begin{array}{l}\text { Sand } \\
\text { mole }\end{array}$} & \multirow{4}{*}{$2-m$} & 0 & \multirow{4}{*}{2517.53} & & & & & \\
\hline & & 10 & & 126560 & 54.98 & 273696 & 148959 & 6904 \\
\hline & & 15 & & 1265.60 & 54.98 & 2736.96 & 1489.59 & 69.04 \\
\hline & & 20 & & & & & & \\
\hline & & 0 & & & & & & \\
\hline & $4 . m$ & 10 & (20360 & 126410 & & & & \\
\hline & 4-m & 15 & 2303.60 & 1264.40 & 58.05 & 2459.55 & 1381.85 & 72.92 \\
\hline & & 20 & & & & & & \\
\hline & & 0 & & & & & & \\
\hline & G m & 10 & 212211 & ח? & & & & \\
\hline & 6-m & 15 & 2123.41 & 1225.20 & 64.25 & 2339.35 & 1298.62 & 72.22 \\
\hline & & 20 & & & & & & \\
\hline Mean & & & 2314.85 & 1251.73 & 59.09 & 2511.95 & 1390.02 & 71.39 \\
\hline
\end{tabular}


Table(7):Field and crop water use efficiency $\left(\mathrm{kg} / \mathrm{m}^{3}\right)$ as affected by different treatments under cultivation of wheat and sunflower crops.

\begin{tabular}{|c|c|c|c|c|c|c|c|c|}
\hline \multirow{2}{*}{\multicolumn{3}{|c|}{ Treatments }} & \multicolumn{4}{|c|}{ Wheat crop } & \multicolumn{2}{|c|}{ Sunflower } \\
\hline & & & \multicolumn{2}{|c|}{ FWUE } & \multicolumn{2}{|c|}{ CWUE } & \multirow{2}{*}{$\begin{array}{c}\text { FWUE } \\
\text { Seed }\end{array}$} & \multirow{2}{*}{$\begin{array}{l}\text { CWUE } \\
\text { Seed }\end{array}$} \\
\hline $\begin{array}{l}\text { Mole } \\
\text { type }\end{array}$ & \begin{tabular}{|c|} 
Mole \\
spacing \\
m
\end{tabular} & $\begin{array}{c}\text { Compost } \\
\text { rates } \\
\text { ton } \text { fed }^{-1}\end{array}$ & Grain & Straw & Grain & Straw & & \\
\hline \multirow{12}{*}{ Mole } & \multirow{4}{*}{ 2-m } & 0 & 1.09 & 1.35 & 2.03 & 2.50 & 0.34 & 0.60 \\
\hline & & 10 & 1.29 & 1.53 & 2.38 & 2.83 & 0.37 & 0.65 \\
\hline & & 15 & 1.42 & 1.72 & 2.62 & 3.18 & 0.43 & 0.75 \\
\hline & & 20 & 1.46 & 1.89 & 2.88 & 3.50 & 0.46 & 0.80 \\
\hline & \multirow{4}{*}{ 4-m } & 0 & 1.14 & 1.43 & 1.94 & 2.44 & 0.34 & 0.59 \\
\hline & & 10 & 1.33 & 1.65 & 2.26 & 2.82 & 0.39 & 0.67 \\
\hline & & 15 & 1.48 & 1.77 & 2.51 & 3.01 & 0.42 & 0.73 \\
\hline & & 20 & 1.61 & 1.94 & 2.73 & 3.30 & 0.48 & 0.83 \\
\hline & \multirow{4}{*}{$6-m$} & 0 & 1.24 & 1.56 & 1.99 & 2.50 & 0.36 & 0.61 \\
\hline & & 10 & 1.39 & 1.73 & 2.25 & 2.78 & 0.40 & 0.69 \\
\hline & & 15 & 1.58 & 1.89 & 2.54 & 3.04 & 0.44 & 0.75 \\
\hline & & 20 & 1.67 & 2.03 & 2.69 & 3.28 & 0.49 & 0.82 \\
\hline \multirow{12}{*}{$\begin{array}{l}\text { Sand } \\
\text { mole }\end{array}$} & \multirow{4}{*}{$2-m$} & 0 & 1.05 & 1.35 & 2.09 & 2.69 & 0.32 & 0.59 \\
\hline & & 10 & 1.24 & 1.50 & 2.48 & 2.99 & 0.36 & 0.66 \\
\hline & & 15 & 1.35 & 1.64 & 2.68 & 3.26 & 0.42 & 0.76 \\
\hline & & 20 & 1.54 & 1.87 & 3.07 & 3.71 & 0.45 & 0.84 \\
\hline & \multirow{4}{*}{ 4-m } & 0 & 1.11 & 1.36 & 2.02 & 2.48 & 0.35 & 0.62 \\
\hline & & 10 & 1.30 & 1.57 & 3.37 & 2.86 & 0.37 & 0.65 \\
\hline & & 15 & 1.42 & 1.71 & 2.59 & 3.12 & 0.44 & 0.78 \\
\hline & & 20 & 1.51 & 1.85 & 2.75 & 3.37 & 0.49 & 0.88 \\
\hline & \multirow{4}{*}{$6-m$} & 0 & 1.23 & 1.42 & 2.13 & 2.46 & 0.36 & 0.65 \\
\hline & & 10 & 1.38 & 1.67 & 2.39 & 2.89 & 0.38 & 0.69 \\
\hline & & 15 & 1.48 & 1.78 & 2.56 & 3.09 & 0.44 & 0.79 \\
\hline & & 20 & 1.51 & 1.88 & 2.71 & 3.26 & 0.51 & 0.92 \\
\hline
\end{tabular}

Data (Table, 7) also showed that, field and crop water use efficiency for both wheat and sunflower were increased with the increasing application rates of compost (from 10 to 20 ton $^{-1} \mathrm{fe}^{-1}$ ) with all mole treatments. Data in Table (7) revealed that the highest values $\left(3.07\right.$ and $\left.3.71 \mathrm{~kg} / \mathrm{m}^{3}\right)$ of crop water use efficiency were achieved with 20 ton fed ${ }^{-1}$ at $2 \mathrm{~m}$ spacing under sandy mole for wheat (grain and straw). Also, the highest value $\left(0.92 \mathrm{~kg} / \mathrm{m}^{3}\right)$ of crop water use efficiency was achieved with 20 ton fed ${ }^{-1}$ at $6 \mathrm{~m}^{\text {spacing under }}$ sandy mole for sunflower seed. The highest values of field and crop water use efficiencies may be due to higher yield obtained and less amount of water applied or consumed. These results are in harmony with those obtained with Zamil (2012) and El-Sanat (2012).

Yield and its components:

Data in Table (8) presented the mean values of wheat and sunflower yields and their components as affected by mole types, mole spacing and compost rates. Results sowed that, mole types, mole spacing and compost rates had highly significant effect on yields and yield components of wheat and sunflower. Sandy mole treatment caused increasing of grain, straw, biological yields and 1000 grain weight of wheat than without sand mole by $74.30,116.1,185.43 \mathrm{~kg} \mathrm{fed}^{-1}$ and $0.31 \mathrm{~g}$, respectively. Also, sand mole caused increase of seed yield, seed oil content, plant height, head diameter 
and 100 seed weight of sunflower than without sandy mole by $48.41 \mathrm{~kg} \mathrm{fed}^{-1}$, $0.26 \%, 5.99 \mathrm{~cm}, 1.03 \mathrm{~cm}$ and $0.05 \mathrm{~g}$, respectively.

Table (8):Yield and their components of wheat and sunflower as affected by different treatments.

\begin{tabular}{|c|c|c|c|c|c|c|c|c|c|c|}
\hline \multirow[b]{2}{*}{ Treat. } & \multicolumn{4}{|c|}{ Wheat } & \multicolumn{6}{|c|}{ Sunflower } \\
\hline & $\begin{array}{c}\text { Grain } \\
\text { yield } \\
\text { kg fed }^{-1}\end{array}$ & $\begin{array}{c}\text { Straw } \\
\text { yield kg } \\
\text { fed }^{-1}\end{array}$ & $\mid \begin{array}{c}\text { Biological } \\
\text { yield kg } \\
\text { fed }^{-1}\end{array}$ & $\begin{array}{c}1000 \\
\text { grain } \\
\text { weight } \\
\text { (g) }\end{array}$ & $\begin{array}{c}\text { Seed } \\
\text { yield kg } \\
\text { fed }^{-1}\end{array}$ & $\begin{array}{c}\text { Seed oil } \\
\text { content } \\
\%\end{array}$ & $\begin{array}{c}\text { Plant } \\
\text { height } \\
\text { (cm) }\end{array}$ & $\begin{array}{c}\text { Stem } \\
\text { diameter } \\
\text { (cm) }\end{array}$ & $\begin{array}{c}\text { Head } \\
\text { diameter } \\
(\mathrm{cm})\end{array}$ & $\begin{array}{c}100 \\
\text { seed } \\
\text { weight } \\
\text { (g) }\end{array}$ \\
\hline & \multicolumn{10}{|c|}{ Mole type (T) } \\
\hline Mole & 2997.1 & 3657.7 & 6656.67 & 58.23 & 972.43 & 32.46 & 163.34 & 1.86 & 17.58 & 6.78 \\
\hline $\begin{array}{l}\text { Sandy } \\
\text { mole }\end{array}$ & 3071.4 & 3773.8 & 6842.10 & 58.54 & 1020.84 & 32.72 & 169.33 & 1.99 & 18.61 & 6.83 \\
\hline \multirow[t]{2}{*}{ F.test } & ** & $\star \star \star$ & 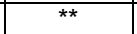 & 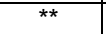 & 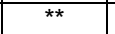 & $\hbar$ & 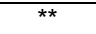 & * & $\star \star$ & * \\
\hline & \multicolumn{10}{|c|}{ Mole spacing (S) } \\
\hline $2-m$ & 2961.3 & 3554.8 & 6474.3 & 58.77 & 978.60 & 31.41 & 162.94 & 1.83 & 17.58 & 6.74 \\
\hline $4-m$ & 2841.58 & 3406.3 & 6248.7 & 57.71 & 949.76 & 31.29 & 158.38 & 1.79 & 16.97 & 6.56 \\
\hline 6-m & 2738.5 & 3311 & 6089.3 & 56.43 & 933.62 & 31.04 & 157.92 & 1.77 & 16.28 & 6.39 \\
\hline F.test & $\star \star *$ & $\star \star$ & $\star \star$ & ** & $\star \star$ & $* *$ & $\star \star$ & * & ** & ** \\
\hline LSD 0.05 & 80.44 & 46.28 & 87.42 & 0.097 & 8.44 & 0.024 & 1.151 & .035 & 0.052 & 0.026 \\
\hline \multirow[t]{2}{*}{ LSD 0.01} & 110.20 & 63.41 & 119.78 & 0.133 & 11.57 & 0.033 & 1.577 & 0.048 & 0.072 & 0.036 \\
\hline & \multicolumn{10}{|c|}{ Compost rate (ton/fed) (C) } \\
\hline 0 & 2349.3 & 2863 & 5269.8 & 52.19 & 808.27 & 28.67 & 139.15 & 1.40 & 12.81 & 5.32 \\
\hline 10 & 2756.0 & 3246 & 6000.2 & 55.42 & 889.98 & 31.11 & 156.02 & 1.67 & 15.83 & 6.06 \\
\hline 15 & 3033.3 & 3633 & 6666.7 & 59.51 & 1013.62 & 32.29 & 167.93 & 1.83 & 17.86 & 6.79 \\
\hline 20 & 3249.7 & 3952 & 7146.61 & 63.43 & 1104.11 & 32.86 & 175.88 & 2.30 & 21.27 & 8.08 \\
\hline F.test & $\star \star \star$ & $\star \star \star$ & $\star \star *$ & $\star \star$ & $\star \star$ & ** & $\star \star$ & ** & $\star \star *$ & ** \\
\hline LSD 0.05 & 88.6 & 50.59 & 101.31 & 0.111 & 9.89 & 0.059 & 0.732 & 0.042 & 0.064 & 0.076 \\
\hline \multirow[t]{2}{*}{ LSD 0.01} & 117.57 & 67.07 & 134.32 & 0.148 & 13.11 & 0.078 & 0.971 & 0.056 & 0.084 & 0.101 \\
\hline & \multicolumn{10}{|c|}{ Interaction } \\
\hline $\mathrm{T} \times \mathrm{S}$ & ** & ** & ** & ** & $\star *$ & ** & ** & * & $\star *$ & ** \\
\hline $\mathrm{T} \times \mathrm{C}$ & $\star \star$ & $\star \star *$ & * & $\star \star$ & $\star \star$ & ** & $\star \star *$ & $\star \star$ & $\star \star$ & ** \\
\hline $\mathrm{S} \times \mathrm{C}$ & NS & 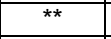 & NS & $\star \star$ & * & NS & ** & NS & $\star \star$ & NS \\
\hline $\mathrm{T} \times \mathrm{S} \times \mathrm{C}$ & NS & NS & NS & ** & NS & NS & $\hbar \star$ & NS & ** & \\
\hline
\end{tabular}

The effect of mole spacing on wheat and sunflower yields and its components can be arranged according to the following descending order $2 \mathrm{~m}$ $>4 \mathrm{~m}>6 \mathrm{~m}$. Whereas, 2-m mole spacing led to increase the grain, straw, biological yields and 1000 grain weight of wheat by $222.8,243.8,385 \mathrm{~kg} \mathrm{fed}^{-1}$ and $2.34 \mathrm{~g}$, respectively than $6-\mathrm{m}$ mole spacing. Also, 2-m mole spacing caused increase of seed yield, seed oil content, plant height, head diameter and 100 seed weight of sunflower by $44.98 \mathrm{~kg} \mathrm{fed}^{-1}, 0.37 \%, 5.02 \mathrm{~cm}, 1.3 \mathrm{~cm}$ and $0.35 \mathrm{~g}$, respectively than $6-\mathrm{m}$ mole spacing. Such findings may be attributed to the effect of mole types and spacing on improving soil properties which caused water-air balance in the root zone, and increasing the amount of available nutrients for the plant. Similar results were obtained by Moukhtar et al., (2002, 2003 and 2012) Antar et al., (2008 and 2012) and Aiad et al., (2012)

Results in Table (8) show that, compost application caused high increases in wheat and sunflower yields and its components than without compost. Also, wheat and sunflower yields and its components were 
increased as result of increasing rates of compost. However, the applied of $15 \& 20$ ton $\mathrm{fed}^{-1}$ compost led to increase the grain, straw, biological yields and 1000 grain weight of wheat by $10.06 \& 17.91,11.92 \& 21.75,11.11 \&$ 19.11 and $7.38 \& 14.45 \%$, respectively than 10 ton fed $^{-1}$ compost treatment.

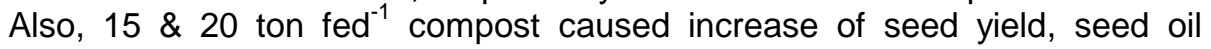
content, plant height, head diameter and 100 seed weight of sunflower by $13.89 \& 24.06,3.79 \& 5.63,7.63 \& 12.73,12.82 \& 34.37$ and $12.05 \& 33.33$ $\%$, respectively than 10 ton fed ${ }^{-1}$ compost. Beneficial effects of compost applications to crops are many and varied. Most of them are due to soil quality improvement and nutrient enhancement which resulted increases in crop quality and yield (Jack, 1995).

Conclusion:

It can be concluded that the combination between sandy mole at $2 \mathrm{~m}$ spacing and application of compost at 20 ton fed $^{-1}$ under cultivation of wheat and sunflower were the appropriate treatments to improve some soil chemical and physical properties, increase available nutrients and increase crop and water productivity of salt affected soils at North Delta.

\section{REFERENCES}

Abdel-Mawgoud, H.S.A.; A.A.S. Gendy and S.A. Ramadan (2006). Improving root zone environment and production of a salty clay soil using subsoiling and gypsum application. Assiut J.of Agric.Sci., 37(2):147-164.

Aiad, M.A.F.; M.A. Abd El-Aziz; B.A.A. Zamil and A.S. Antar (2012). Combating of soil deterioration at North Delta. Egypt. J. Agric. Res. Kafrelsheikh Univ., 38(2): 322-341.

Ali, M.H.; M.R. Hoque; A.A. Hassan and A. Khair (2007). Effects of deficit irrigation on yield, water productivity, and economic returns of wheat. Agricultural Water Management, 92(3): 151-161.

Amer, M.H. (1999). Effect of tillage operations on some soil physical properties and water relations of corn. Egypt. J. Appl. Sci., 14(6): 354365.

Antar, S. A.; A. S. El-Henawy and A. A. E. Atwa (2008). Improving some properties of heavy clay salt affected soil as a result of different subsurface tillage. J. Agric. Sci. Mansoura Univ., 33 (10): 7675- 7687.

Antar, S. A.; Mohamedin, A.A.M. and El-Meligy, A.M. (2012). Improving root zone and production of clay salt affected soil as a result of different subsurface tillage. $11^{\text {th }}$ ICID International Drainage Workshop on Agricultural Drainage Needs and Future Priorities. Cairo, Egypt September $23-27,2012$.

A.O.A.C. (1990). Official methods of Analysis of the association of official Analytical chemists, $15^{\text {th }}$ (edition, published by Association of official Analytical chemists), Arlington, Virginia, U.S.A.

Campbell, D.J. (1994). Determination and use of bulk density in relation to soil compaction. In Soane and Ouwerk (Eds). Soil Compaction in Crop Production. Elsevere, London, Amsterdam.

David, H.C. (2002). Managing wet soils: Mole drainage. www.dse.vic.gov. 
Doran, J.W. and T.B. Parking (1994). Defining and assessing soil quality, in defining soil quality of a sustainable environment, Doran J.W.; Coleman, D.C.; Bezdicek, D.F. and Steward, B.A. Eds., SSSA Special Publication Number 35, SSSA, Madison, WI, 3.

Downy, L.A. (1970). Water Use by Maize at Three Plant Densities, Paper 33, FAO, Rome.

Early, A.C. (1975). "Irrigation Scheduling for wheat in the Punjab. CENTO Scientific Programme on the optimum use of water in Agriculture. Repot No. 17, Lyallpur, Pakistan, March 3-5, pp. 115-127.

El-Sanat, G.M.A. (2012). Effect of some soil management practices and nitrogen fertilizer levels on some soil properties and its productivity at North Delta. J. Soil Sci. and Agric. Eng., Mansoura Univ., 3(12): 11371151.

Enkeliu, Chagrong Yan; Xurong Mei; Wnging He; So Hwat Bing; Linping Ding; Qin Liu; Suang Liu and Tinglu Fan (2010). Long term effect of chemical fertilizer, straw and manure on soil chemical and biological properties in northwest China, 158: 173-180.

Garcia, I. (1978). Soil Water Engineering Laboratory Manual Department of Agricultural and Chemical Engineering. Colorado State Univ., Colorado, USA.

Gong, W.; X. Yan; J. Wang;T. Hu and Y.Gong (2009).Long term manure and fertilizer effects on soil organic matter fractions and microbes under a wheat-maize cropping system in northern China. Geoderma149:318324.

Hansen, V.W.; O.W. Israelsen and G.E. Stringharm (1979). Irrigation principles and practices. $9^{\text {th }}$ ed. John Willey and Sons Inc., New York, USA.

Hussain, N.; G. Hassan; A. Ghafoor and G. Sarwar (1998). Bio-amelioration of sandy saline sodic soil. Proc. $6^{\text {th }}$ Int. Micro-Irrigation Congress, March 8-10, 1998, Florida, p. 293-300.

Ibrahim, S.M.; J. Blankenburg and H. Kuntze (1999). Drainage effects in Marsh oil. II. Effects on soil properties and grain yield. Z.F. Kutturtech and Landentwick, 40(2): 72-76.

Keeney, D.R. and J.M. Bremner, (1966). Determination and isotope ratio analysis of different forms of nitrogen in soils. Soil Sci. Soc. Am. Proc. 30: 583-594.

Klute, A. (1986). Methods of Soil Analysis (part 1). American Society of Agronomy, Inc. Soil Sci. Soc. Amer., Inc. Madison, Wisconsin, USA. Second Edition

Klute, A. (1986). Methods of soil analysis, Part 1: Physical and Mineralogical methods ( $2^{\text {nd }}$ ed.). Am. Soc. of Agron. Inc. Soil Sci. of Agron Inc. Madison, Wisconsin, USA.

Moukhtar, M.M. and A.I.N. Abdel-aal Khalik (2002). The role of mole drainage in degradation soil under saline ground water table, Egypt. The Second International Conference on Sustainable Agric. for Food, Energy and Industry, September 8-13 Beijing, China. 
Moukhtar, M.M.; Madiha H. El-Hakim, Aly I. N. Abdel-Aal, Aly.S.A. AbdelMawgoud, Mohamed A. B. El-Sheikh and Mohamed Ismail (2012). Mole Drainage in Egyptian Salty Clay Soil. $11^{\text {th }}$ ICID International Drainage Workshop on Agricultural Drainage Needs and Future Priorities. Cairo, Egypt September 23 - 27, 2012.

Moukhtar, M.M.; Madiha, H. El-Hakim; A.S.A. Abdel-Mawgoud; A.I.N. AbdelAal and M.A.B. El-Shewikh (2003). Drainage and role of mole drains for heavy clay soils under saline water table, Egypt paper No. 078 presented at the $9^{\text {th }}$ International Drainage Workshop. September 1013, 2003 Utrecht, The Netherlands.

Moustafa, A.T.A.; W.A Ahmed; C.C. Chang and G.J. Hofman (1987). Influence of depth and spacing of tile drainage on crop productivity in Nile Delta Trans. ASAE, 30(5): 1374-1377.

Olsen, S.R.; Cale, C.V.; F.S. Watanabe, and L.A. Dean, (1959). Estimation of available phosphorus in soil by extraction with sodium bicarbonate. USDA, Circ., 939.

Page, A.L. (1982). Methods of soil analysis. Part 2: Chemical and microbiological properties, $2^{\text {nd }}$ Ed. Amer. Inc. Madison Wisconsin, USA Chapter 12: 194-223.

Page, A.L.; R.H. Miller and D.r. Keeney (1982). Methods of Soil Analysis. Part 2: Chemical and Microbiological Properties $2^{\text {nd }}$ ed. Soil Sci. Am. Inc., Madison, USA.

Richards, I.A. (1954). Diagnosis and Improvement of Saline and Alkali Soils. Agric. Handbook No. 60, USA, D. Chapter 7, pp. 83-126.

Said, H.M. (2003). Effect of tillage implements on the state of compacted different soils. Egypt. J. Soil Sci. 43: 91-107.

Shama, D.P. and S. Komal (1998). Effect of subsurface drainage system on some physicochemical properties and wheat yield in water logged saline soil. J. Indian Soc. Soils Sci., 46(2): 284-288.

Shams El-Din, H.A. (2001). Productivity of heavy clay soils as affected by soil amendments and drainage treatments. J. Agric. Sci. Mansoura Univ., 26(12): 8169-8180.

Singh, G.; P.N. Singh and L.S. Bhushan (1980). Water use and wheat yields in Northern India under different irrigation regimes. Agric. Water Management, 3: 107-114.

Snedecor, G.W. and W.G. Cochran (1982). Statistical Methods. $7^{\text {th }}$ Ed., lowa State Univ. Press, Ames., lowa, USA.

Spaccini, R.; A. Piccolo; J.S.C. Mbagwa; T.A. Zena and G.A. Igwe (2002) Influence of the addition of organic residues on carbohydrates content and structural stability of some highland soil in Ethiopia. Soil Use and Mgt. 18: 404-411.

Yassen, A.A.; Ks.M. Khaled and S.M. Zaghloul (2010). Response of wheat to different rates and ratios of organic residues on yield and chemical composition under two types of soil. Journal of American Science, 6(12).

Zamil, B.A. (2012). Effect of mole drain spacing and filling material on some soil properties, yield of flax and kenaf and some water relations in the north middle Nile Delta. Minufiya J. Agric. Res. Vol. 37, No. 4(2):10071017. 
تاثير انفاق الصرف واضافه الكمبوست علي بعض خواص التربـه والعلاقات المائيه وانتاجيه المحاصيل في شمال الألتا محمود ابو الفتوح محمود عياد معهد بحوث الاراضى والمياه والبيئة ـ مركز البحوث الزراعية ـ مصر

أجريت تجربة حقلية بالمزر عة البحثية بمحطة البحوث الزر اعية بسخا بمحافظة كفر الثيخ لتقييم

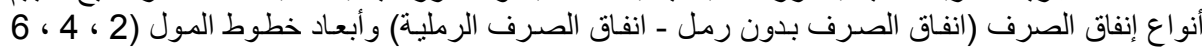

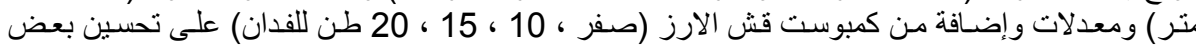

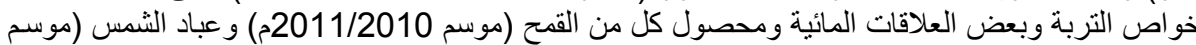

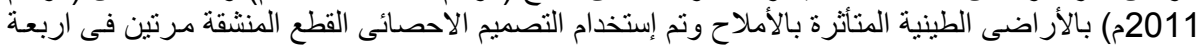

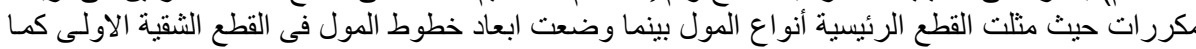
وضعت معدلات إضافة الكومبوست في القئ القطع الثقية الثانية.

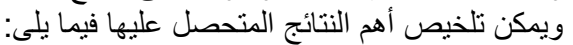

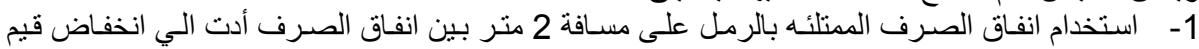
التوصيل الكهربي ونسبه ادمصاص الصوديوم مقارنا بالمول بذون رمل على مسافه 6 متر بين انفاق النقان الصرف

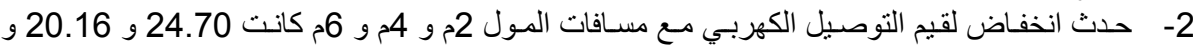

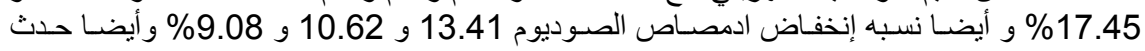

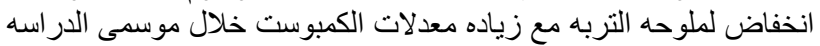

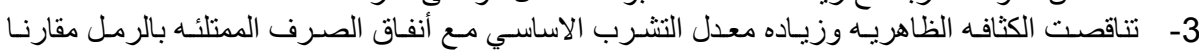

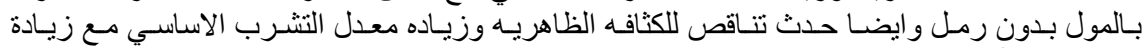

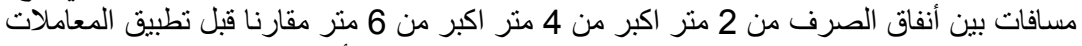

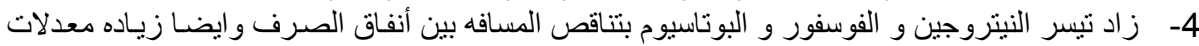

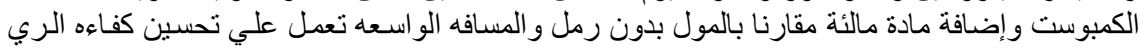
التطبيقيه وايضا استخدام المبياه

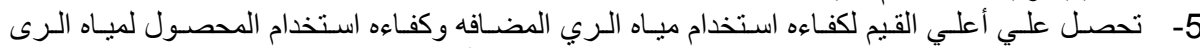

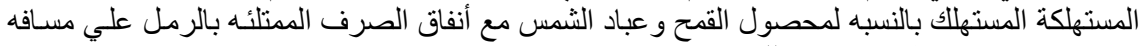

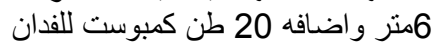

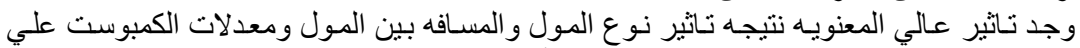

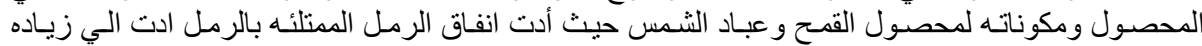

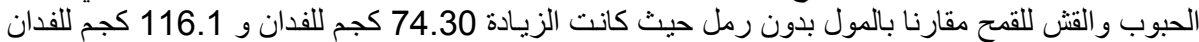

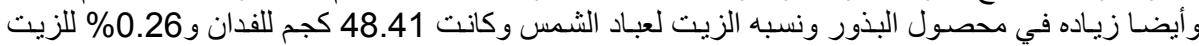

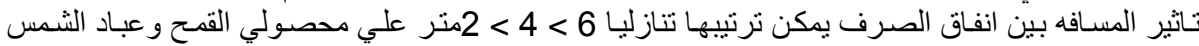

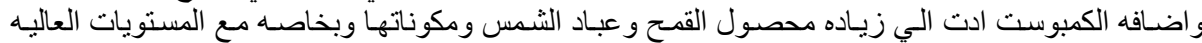

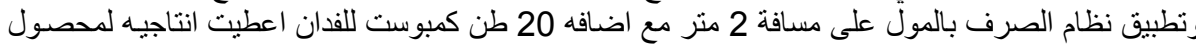
القمح حبوب 3886.7 كجم.

كلية الزراعة - جامعة المنصورة مركز البحوث الزراعية
قام بتحكيم البحث أ.د / احمد عبد القادر طة الدمة

أ.د / محمود محمد سعيد الد طيد 